\title{
PROPOSAL FOR STRUCTURAL EVALUATION OF HISTORICAL CHURCHES AT LIMA, PERU
}

\author{
C. CUADRA \\ Akita Prefectural University, Japan.
}

\begin{abstract}
The historic centre of Lima city, the capital of Peru, was declared a World Heritage Site in 1988 by UNESCO. The high concentration of historic monuments constructed at the time of the Spanish presence and at the beginning of the Republican era, contributes to originality and historic value of the site. Churches or convents are included in this area, and according to a list of Ministry of Culture of Peru there are 50 places considered religious monuments. As a contribution to improve urban security and safety against earthquakes, in this study, a procedure to investigate the seismic vulnerability of these churches is discussed. First, a general diagnosis of problems concerning the city and its buildings is proposed. Then a survey for preliminary evaluation of the structural condition of churches structures is planned. This evaluation of the seismic vulnerability of historic churches at the historic centre of Lima represents the basic study that is necessary to initiate detailed investigation for the preservation and conservation of these historic buildings. The study intends to establish a general guideline for vulnerability evaluation of historic churches Lima Heritage Site and it could be applied to the evaluation of other historic cities of Peru.
\end{abstract}

Keywords: ambient vibration, architectural heritage, historic churches, Lima city, seismic vulnerability.

\section{INTRODUCTION}

A diagnosis for evaluation of seismic vulnerability of historical building located in Lima, Peru, was performed by Cuadra et al. in 2013 [1]. In the present research, only historical churches are included, since these structures are more representative buildings of the historic landscape of Lima centre.

The historic centre of Lima city was declared a World Heritage Site in 1988 for its originality and high concentration of historic monuments constructed at the time of the Spanish presence and at the beginning of the republican era. The architecture of the buildings corresponds in general to typical Hispano-American baroque of the 17th and 18th centuries. Lima city was founded on January 18, 1535, by Spaniard conquistador Francisco Pizarro and played a leading role in the history of the New World from 1542, when king Carlos V of Spain establish the vice royalty of Peru, until the middle of the 18th century, just before the start of independence movements [1].

Conservation of historic buildings is an important task that implies, as a first step, the evaluation of their vulnerability. Evaluation of the vulnerability of a single building could mean the estimation of mechanical characteristics by means of detailed structural analysis or in-situ measurements. When this evaluation must be performed for a group of buildings, however, simplified evaluation is required to establish their characteristics and hence to grasp the vulnerability of target buildings. For a preliminary evaluation of structural conditions of target churches, a general survey is planned to be undertaken. For this purpose, a simple methodology for estimating earthquake resistance or vulnerability of target churches is proposed.

This evaluation of the seismic vulnerability of churches located at historic centre of Lima represents a basic study that is necessary to initiate detailed investigation for the preservation and conservation of these historic churches. A method is proposed based on simple indexes to establish the potential vulnerability of buildings. Detailed observation and in-situ 
estimation of the dynamic characteristics of critical buildings is then proposed by using ambient vibration measurements. Measurements results will permit to verify the analytical models for detailed structural analysis to establish the vulnerability of specific target buildings.

Study of vibration characteristics of soil is also a critical task to identify possible cases of resonance effect that could affect or amplify vibration response of buildings. This evaluation can be done also by means of microtremor measurements on ground surface to identify the predominant period of vibration of soil.

This process of evaluation of seismic vulnerability could also serve to establish a general guideline for vulnerability evaluation of churches or in general historical buildings located at other historic cities in Peru.

\section{CHURCHES AT HISTORIC CENTRE OF LIMA}

Description of characteristics of Lima historic centre and historical churches are taken from reference [1]. At the time of the founding of Lima by the Spaniards conquistadores, the site was occupied by a local government called Curacazgo and the Governor, who was the local representative of the Inca emperor, was called Curaca. Only temples called Huacas and administrative constructions existed at that time, and they were replaced by Spanish-style constructions. The city was organized in a shape of a chessboard following the original Inca distribution of streets. This portion can be appreciated in the central part of Fig. 1 enclosed by a dashed-line polygon, where straight streets and square blocks can be observed. Sometimes this portion of the city alone is called the historic centre. However, the area declared by UNESCO to be a World Heritage Site is larger, as is indicated in Fig. 1 by the area enclosed by a solid-line irregular polygon.

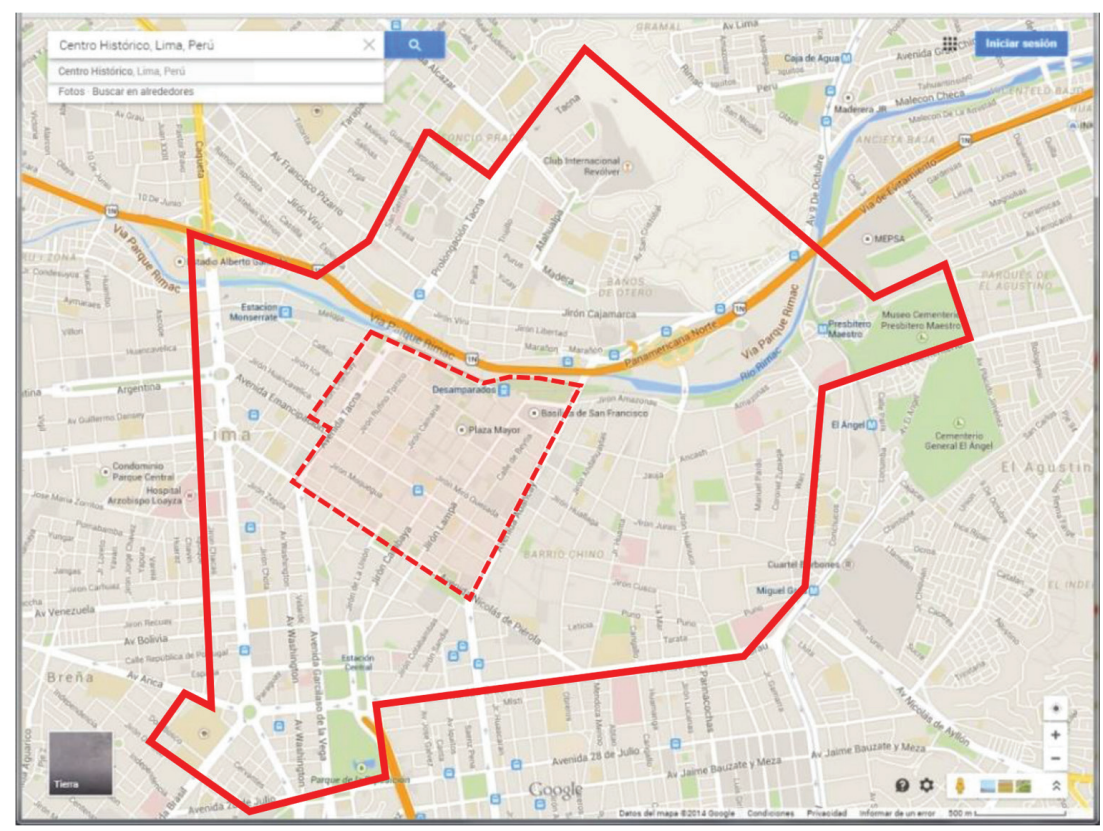

Figure 1: Lima city world heritage site area (Google map). 
The Ministry of Culture of Peru has elaborated a catalogue of historic monuments located at centre of Lima. In the case of the evaluation of the vulnerability of an area of the city, characteristics of buildings located at this site must be studied, and this task is crucial in the case of historic constructions. An understanding of the characteristics of existing buildings is important to the assessment of their structural safety. At historic centre of Lima, buildings can be divided according to their use. In this case, important buildings include churches in 50 places considered religious monuments. Then there are buildings that were used as residences, institutions like banks, commercial shops, hotels, and finally some palaces or administrative offices like city hall and the presidential palace. Since there are many types of monuments, it would be adequate to choose some specific types of buildings to initiate vulnerability evaluation. Table 1 shows the places at Lima's historical centre that are religious constructions like churches, convents, and cathedrals.

Table 1: List of religious buildings at Lima's historical centre.

\begin{tabular}{|c|c|c|c|}
\hline ID & Name & ID & Name \\
\hline 1 & El Milagro Chapel & 27 & San Francisco Church \\
\hline 2 & Santa Rosa Monastery & 28 & Santa Clara Church \\
\hline 3 & T. Francisco Monastery & 29 & Concepcionistas Church \\
\hline 4 & 3 St. Francisco Monastery & 30 & Santa Ana Church \\
\hline 5 & San Pedro Monastery & 31 & La Trinidad Church \\
\hline 6 & Cathedral and El Sagrario & 32 & Las Nazarenas Church \\
\hline 7 & Mercedarias Monastery & 33 & Las Trinitarias Church \\
\hline 8 & San Agustin Monastery & 34 & Sra. El Prado Church \\
\hline 9 & Veracruz Church & 35 & Santa Catalina Church \\
\hline 10 & Santo Cristo Church & 36 & Santa Rosa Church \\
\hline 11 & San Carlos Church & 37 & Sra. Del Carmen Church \\
\hline 12 & Jesus Maria Church & 38 & Recoleta Church \\
\hline 13 & La Merced Monastery & 39 & Concepcion Monastery \\
\hline 14 & La Soledad Church & 40 & Bishop Palace \\
\hline 15 & Cocharcas Church & 41 & Santa Rosa Sanctuary \\
\hline 16 & Concepcion Church & 42 & Santo Domingo Monastery \\
\hline 17 & Monserrate Church & 43 & Sra. de la Cabeza Church \\
\hline 18 & San Agustin Church & 44 & Paulo Nuevo Church \\
\hline 19 & San Marcelo Church & 45 & San Lazaro Church \\
\hline 20 & San Pedro Church & 46 & Santa Liberta Church \\
\hline 21 & San Pedro Nolasco Church & 47 & Del Rosario Church \\
\hline 22 & San Sebastian Church & 48 & Sra. Copacabana Church \\
\hline 23 & Santiago Church & 49 & Del Parocinio Church \\
\hline 24 & Santo Domingo Church & 50 & Los Descalzos Church \\
\hline 25 & Corazon de Jesus Church & 51 & San Francisco de Paula \\
\hline 26 & La Buena Muerte Church & & Monastery \\
\hline
\end{tabular}


In this paper, churches are proposed as target constructions because they present a critical or weak part, which is the bell tower. In the case of earthquakes, these towers failed dramatically as was observed in previous earthquakes. Figure 2 shows some churches located at Lima historic centre. Churches have one or two bell towers, which are the most vulnerable part of structure.

Lima city has suffered the effects of many earthquakes. One of them occurred in 1687 and the city was rapidly reconstructed under the influence of the baroque style that had great influence on architectural development in the next two centuries. A big earthquake that destroyed Lima and its port of Callao occurred in 1746. Callao port was also affected by a tsunami originating in the earthquake. This earthquake marks the decline in the Lima Baroque style that had been supported mainly by religious organizations. At the beginning of the republican era, new construction was influenced by New European Baroque. From 1920 to 1940, the architecture of the city was greatly influenced by English urban style based on the concept of the 'Garden City'. With the expansion of Lima, the decay of the historical centre

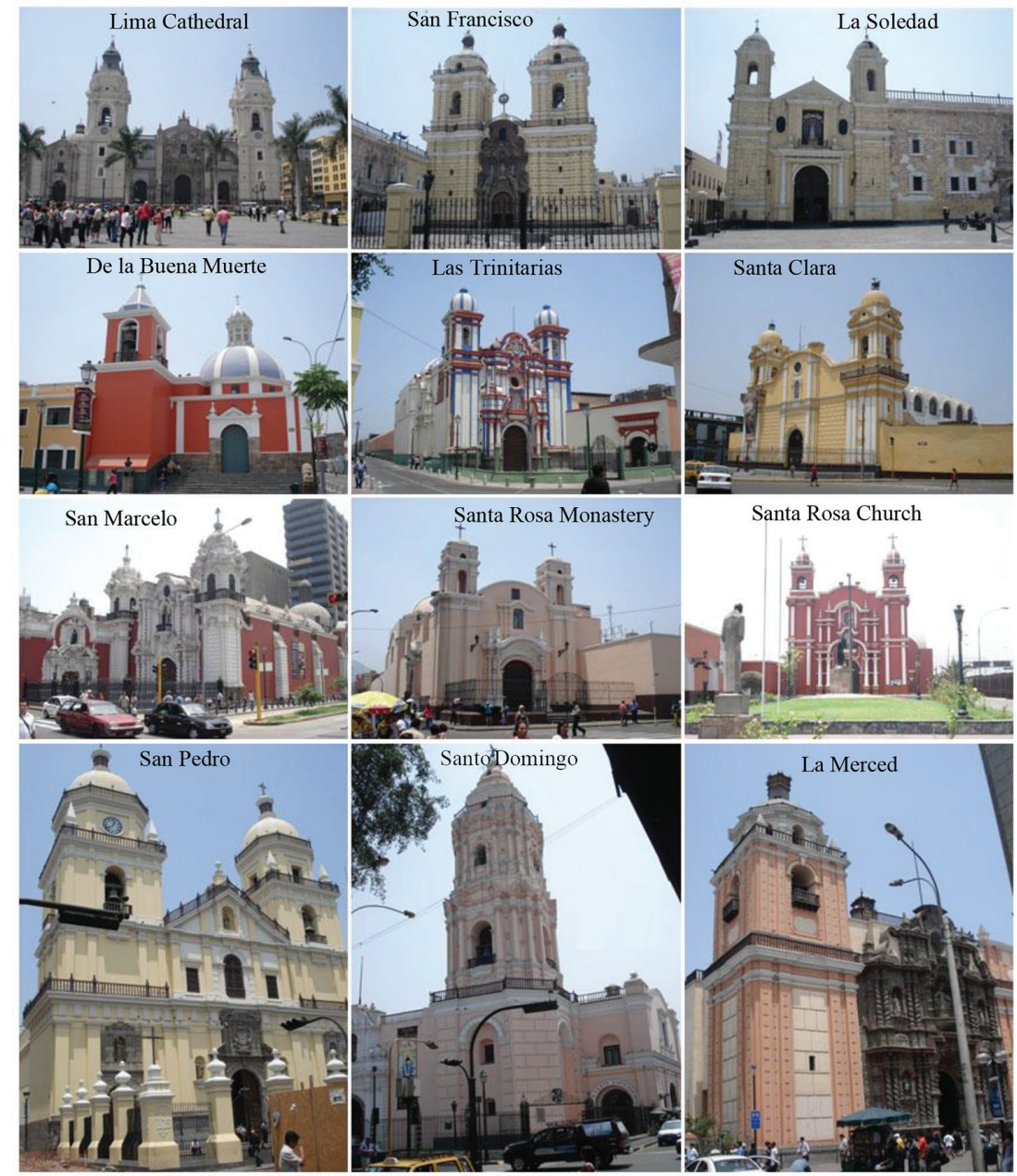

Figure 2: Examples of churches located at Lima historic centre. 
also started, since rich and middle class persons moved to the new urban areas. The historical centre became the place of residence for the poor, who subdivided the buildings and converted them into slams. Some buildings, however, were converted or adapted to serve as commercial shopping centres and educational institutions. In the worst case these old buildings were demolished to construct apartment and office buildings, thereby distorting traditional urban space.

On the other hand, it is also necessary to consider geotechnical properties of ground foundation since soil predominant periods with similar values to predominant periods of structures can result in occurrence of resonance vibration with subsequent structural damage and even collapse. Figure 3 shows distribution of soil type of Lima city reported by Quispe [2], where alluvial gravel deposits cover large part of the city, and presents good geo-mechanic behaviour. Soil of Lima centre is characterized by relatively high predominant frequencies around 3-8 Hz. However, some measurements show also predominant peaks at about 1-2 Hz. This result suggests the presence at the surface of relatively softer soil layers that might contribute to the local response at this site, so it is required to carry out further studies in order to have a better understanding. Therefore, specific measurement of soil dynamic characteristic at each site is required.

\section{PROPOSAL FOR STRUCTURAL EVALUATION}

It is proposed to initiate a detailed survey evaluation to obtain general characteristics of churches. Then, based in the simplified method proposed by Lourenço and Roque [3] a first evaluation of seismic vulnerability can be done. This method considers simple indexes like In-plan area ratio, which is the relation between in-plan area of earthquake resistant walls and total in plan area of the building. The second index is the area to weight ratio, which considers the ratio between in-plan area of earthquake resistant walls and weight of the building. The last index corresponds to the base shear ratio.

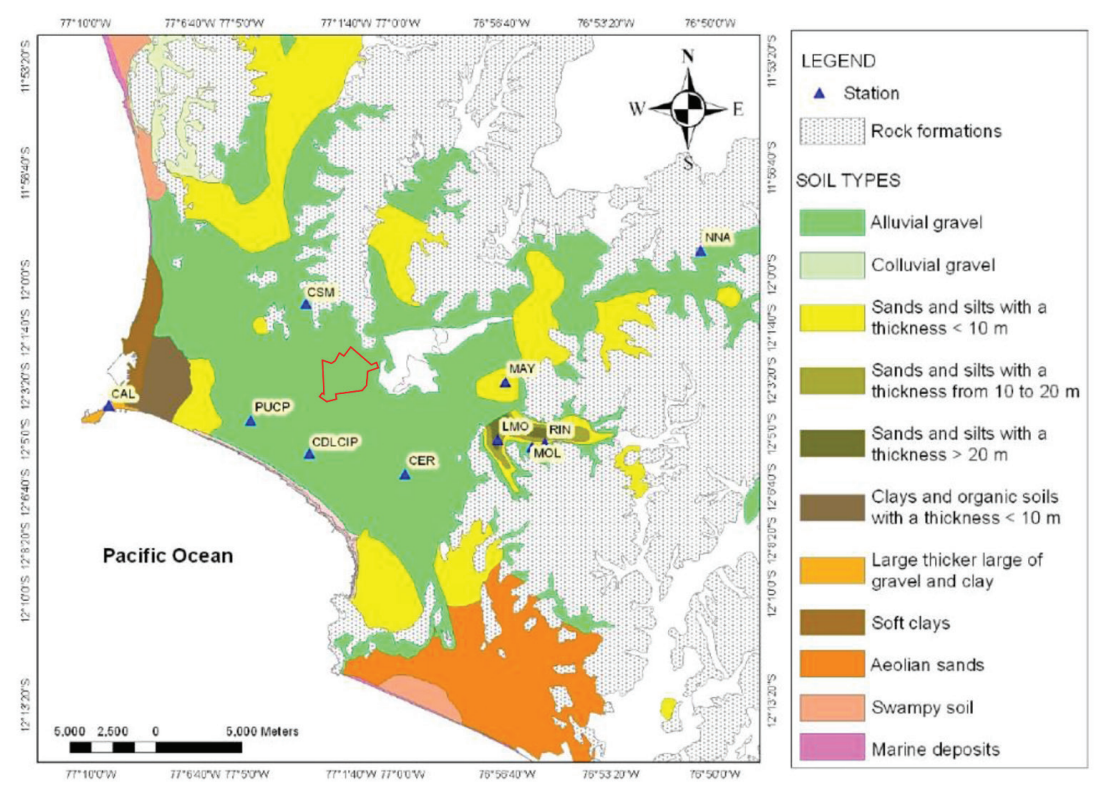

Figure 3: Type of soils at Lima city. 
After the simple evaluation using simple indexes it is proposed to estimate vibration characteristics of churches using ambient vibration measurements. In this case special attention must be put on estimation of vibration of bell towers since these portions of structure are more vulnerable in case of earthquakes. Using results from ambient vibration measurements, a characterization of churches located at Lima historic centre can be done by comparing period of vibration versus structures height. In addition, characteristics of soil at each site can be obtained from ambient vibration measurement on ground.

For some specific or special churches, analysis can be done using finite element method. Reliability of model for analysis can be confirmed by comparing analytical results for period of vibration with those results obtained from ambient vibration measurements ([4-6]).

As example, results of ambient vibration measurements and finite element for Santo Domingo church located in Cusco city, Peru is presented in following paragraphs. Figure 4 shows the Church façade with the bell tower and directions of measurements are indicated by arrows.

Figure 5 presents the results of the Fourier analysis for the horizontal vibration of tower of Santo Domingo church. These directions NS and EW are indicated in Fig. 4. The Fourier amplitude spectrum obtained at the top of the tower was divided by the one obtained at the ground level, to obtain only the vibration characteristics of the structure. It can be observed that the value of the predominant frequency in the EW direction is $2.7 \mathrm{~Hz}$, and in the NS

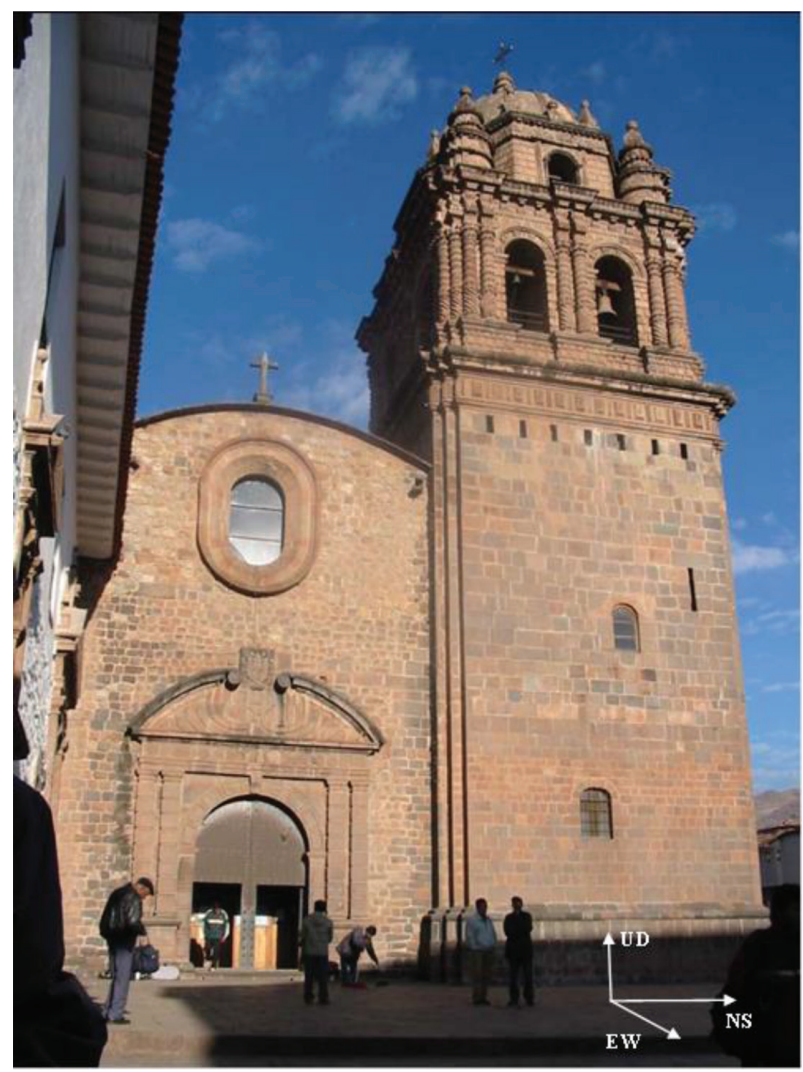

Figure 4: Santo Domingo Church, Cusco, Peru and direction of measurements. 


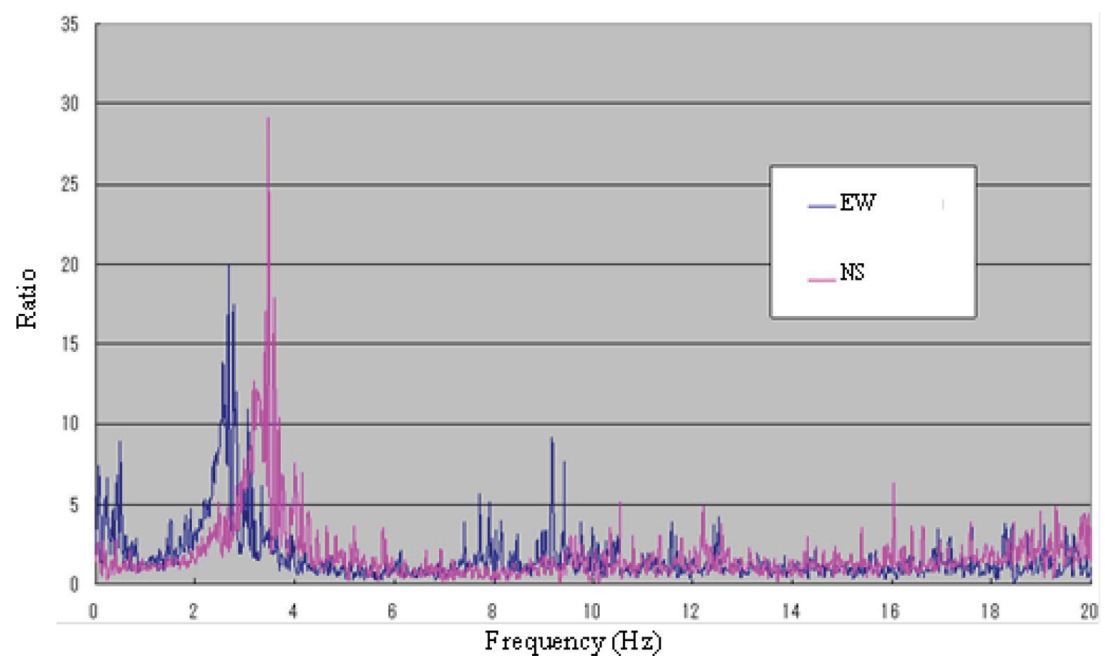

Figure 5: Fourier analysis results for the tower of Santo Domingo Church.

direction is $3.3 \mathrm{~Hz}$. Figure 6 presents the dispersion curve obtained from the FK analysis. This result permits to estimate the predominant frequency of the ground as $2.7 \mathrm{~Hz}$.

Comparing results of predominant frequency for ground with predominant frequencies for the tower of the Colonial Church, it can be observed that these frequencies are similar, and therefore, the resonance phenomenon is expected to occur. This coincidence of the predominant frequencies could be the explanation of the repeatedly failure of the tower during past earthquakes.

To compare the characteristics obtained from ambient vibration measurements with analytical results, finite element method is employed to formulate the analytical model. The FEM model was constructed based on available data and based on direct measurements of the dimension of the building. As can be observed in Fig. 7, the general shape of the Santo Domingo Church is reproduced in the model where only main openings (main door and windows of the tower) are considered.

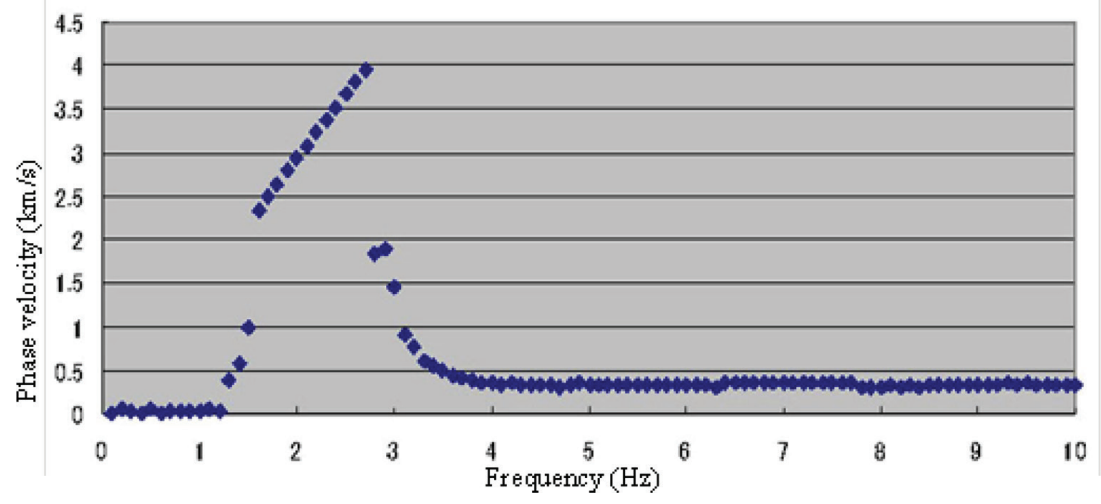

Figure 6: Rayleigh wave dispersion curve for Santo Domingo church ground site. 

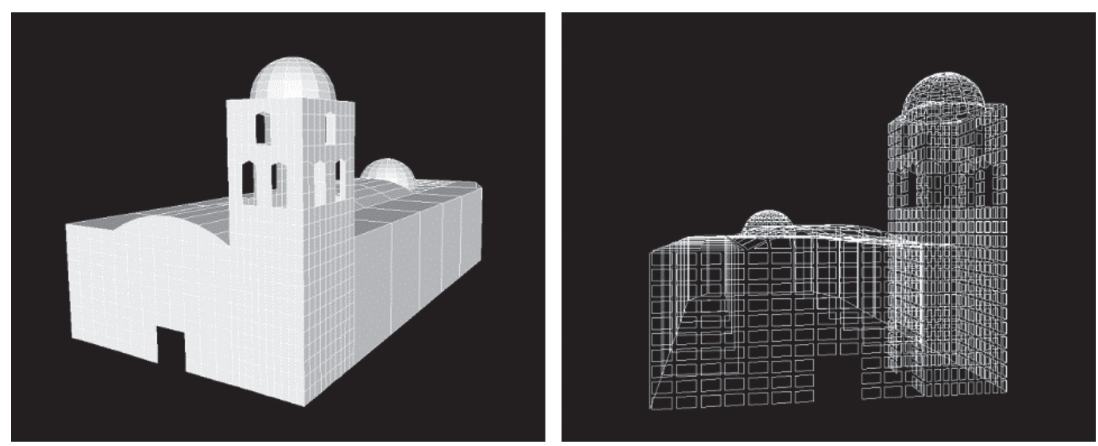

Figure 7: Finite element model of Santo Domingo Church.
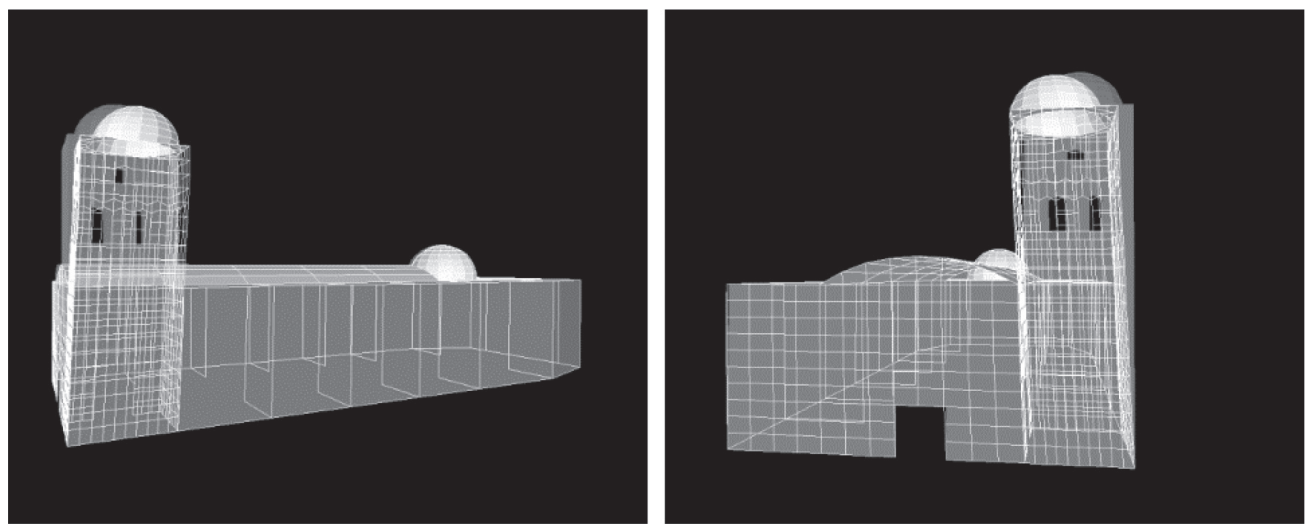

Figure 8: Modes of vibration of Santo Domingo Church.

Modal analysis using the finite element method gives as a result that the first mode of vibration corresponds to normal mode in the $\mathrm{EW}$ direction (or in the longitudinal direction of the church) with a frequency of $3.66 \mathrm{~Hz}$. The second mode corresponds to the vibration in the transversal direction with a frequency of $3.69 \mathrm{~Hz}$. These modes of vibration are show in Fig. 8 where the grey shadow indicates the un-deformed shape of the church.

\section{CONCLUSIONS}

A description of general characteristic and condition of historic churches located at historic centre of Lima was presented. This historical site includes 51 religious monuments like churches and convents, which have some critical conditions for structural safety. As was observed in previous earthquakes, church towers could fail in case of earthquakes. Therefore, churches were proposed as target structures for vulnerability evaluation. This proposal can contribute to improve urban security and safety against earthquakes, in special safety and security of historical centres.

As a process or research methodology for selected target churches, it has been proposed to perform first a rapid survey to establish a priority list for starting detailed evaluation. The classification of vulnerability of historic churches provides the opportunity to focus more detailed measurement on the most critical buildings. Then, for selected churches, ambient 
vibration measurements have been proposed to estimate dynamic characteristics of buildings, in special vibration of bell towers. From these measurements, it is possible to establish indexes of the seismic vulnerability for historic churches. It is also important to estimate vibration characteristics of soil to estimate possible cases of resonance response.

Once a list of most vulnerable churches is established, critical structures could be selected for more detailed analysis. In this case, analytical models using the finite element method or some similar method should be prepared. Ambient vibration measurement results could be used to calibrate the reliability of modelling.

This process of evaluation of seismic vulnerability could also serve to establish a general guideline for vulnerability evaluation of churches or in general historical buildings located at other historic cities in Peru.

\section{REFERENCES}

[1] Cuadra, C., Saito, T. \& Zavala, C., Diagnosis for seismic vulnerability evaluation of historical buildings in Lima, Peru. Journal of Disaster Research, 8(2), pp. 320-327, 2013.

https://doi.org/10.20965/jdr.2013.p0320

[2] Quispe, S., Aguilar, Z., Lazares, F., Tavera, H., Yamanaka, H. \& Yamazaki, F., Evaluation of local site effects in Lima city, Peru from ground motion data, International Symposium for CISMID 25th Anniversary: Technological advances and learned lesson from last great earthquakes and tsunamis in the world, National University of Engineering, Lima, Peru, 2012.

[3] Lourenço, P.B. \& Roque, J.A., Simplified indexes for the seismic vulnerability of ancient masonry buildings. Construction and Building Materials, 20(4), pp. 200-208, 2006. https://doi.org/10.1016/j.conbuildmat.2005.08.027

[4] Cuadra, C., Karkee, M.B., Ogawa, J. \& Rojas, J., An evaluation of earthquake risk to Inca's historical constructions, Proceedings of the 13th World Conference on Earthquake Engineering, Vancouver, B.C., Canada, August 1-6, 2004.

[5] Cuadra, C., Zavala, C., Abe, A., Saito, T. \& Sugano, S., Vibration characteristics of traditional adobe-quincha buildings located at Lima historic center, 8th International Conference on Urban Earthquake Engineering, Tokyo Institute of Technology, Japan, 2011.

[6] Miranda, O., Gallardo, J., Cuadra, C. \& Ogawa, J., Reduction of seismic damage in Peruvian traditional constructions, 2nd International Conference on Computer Simulation in Risk Analysis and Hazard Mitigation, Risk Analysis II, Bologna, Italy, pp. 389-396, 2000. 